\title{
12. GEOCHEMISTRY OF BASALTS FROM THE NORWEGIAN-GREENLAND SEA, LEG 38, DSDP
}

H. Raschka and F.-J. Eckhardt, Bundesanstalt für Geowissenschaften und Rohstoffe, Hannover, Germany

\section{INTRODUCTION}

The main objectives of these investigations on basalts of the Norwegian-Greenland Sea have been the registration of geochemical variations at the nine sites with basaltic basement, and the discovery of variable volcanic regimes in areas of different tectonic setting and age of the basement. The continental break-up, and the spreading history since early Eocene time, as well as the influence of the Iceland-Faeroe plume activity should be represented by specific types of volcanism either derived from a primary hot mantle plume or a depleted low velocity layer (Schilling and NoeNygaard, 1974). Chemical analyses for major and certain trace elements have been carried out for all specimens with the X-ray-fluorescence method (Litetraborate glass discs) using a Philips PW 1450spectrometer.

The results for each sample with a total water content not higher than 4.30 weight $\%$ are shown in tables in the appropriate Site Report chapters (this volume), together with CIPW norms, normative plagioclase content (Norm.Plag.An.), Color Index (C.I.), and Differentiation Index (D.I. $=\mathrm{Q}+\mathrm{Ab}+\mathrm{Or}$ ).

Because of the restriction on samples with a low to medium water content, i.e., with not too high a degree of alteration, samples of Sites 343 and 345 do not have discussions or tables in the Site Report chapters. Only in some figures, in this paper where elements were correlated, which are more resistant against alteration processes, were the analytical data of Sites 343 and 345 also plotted. Figures 1-15 illustrate the geochemical data discussed in this paper.

\section{ALTERATION PROBLEMS}

Fresh basalts were seldom found among the basement rocks of Leg 38 . Only $14 \%$ out of 67 samples gave a total water content below $2 \%$ (weight). About $50 \%$ of these basalts have $2-3 \% \mathrm{H}_{2} \mathrm{O}$, the others show water content higher than $3 \%$.

With increase of water, a systematic change of other elements was noted: $\mathrm{SiO}_{2}$ and $\mathrm{FeO}$ decrease (Figures 13), $\mathrm{K}_{2} \mathrm{O}$ and $\mathrm{Fe}_{2} \mathrm{O}_{3}$ increase. The $\mathrm{H}_{2} \mathrm{O}$ content and the degree of iron oxidation show a positive correlation. From the literature an increase of $\mathrm{MgO}$ was expected with increasing water content, but it was not clearly obvious within the range between $1 \%$ and $4 \% \mathrm{H}_{2} \mathrm{O}$. On the other hand, there are some elements which are more resistant against the influence of alteration: $\mathrm{TiO}_{2}$ (Figure 4), $\mathrm{Zr}, \mathrm{Nb}, \mathrm{Y}$, and to some extent $\mathrm{Sr}$. Vanadium, $\mathrm{Cr}$, and $\mathrm{Sc}$ show either no changes or minor changes of concentration with increase of alteration. Only these elements could be used with some cer-

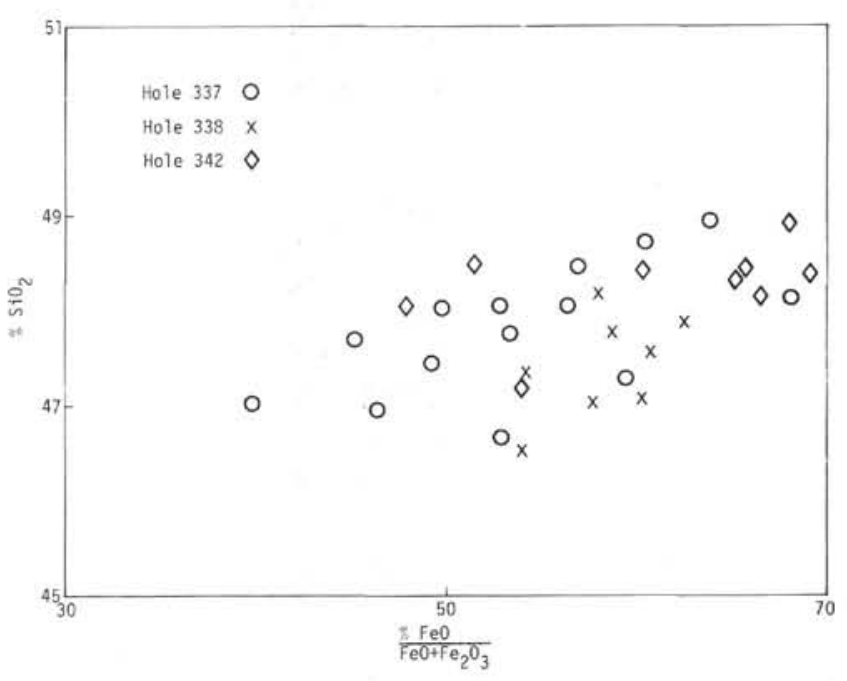

Figure 1. $\% \mathrm{SiO}_{2}$ vs \% $\frac{\mathrm{FeO}}{\mathrm{FeO}+\mathrm{Fe}_{2} \mathrm{O}_{3}}$ for basalts from Sites $337,338,342$.

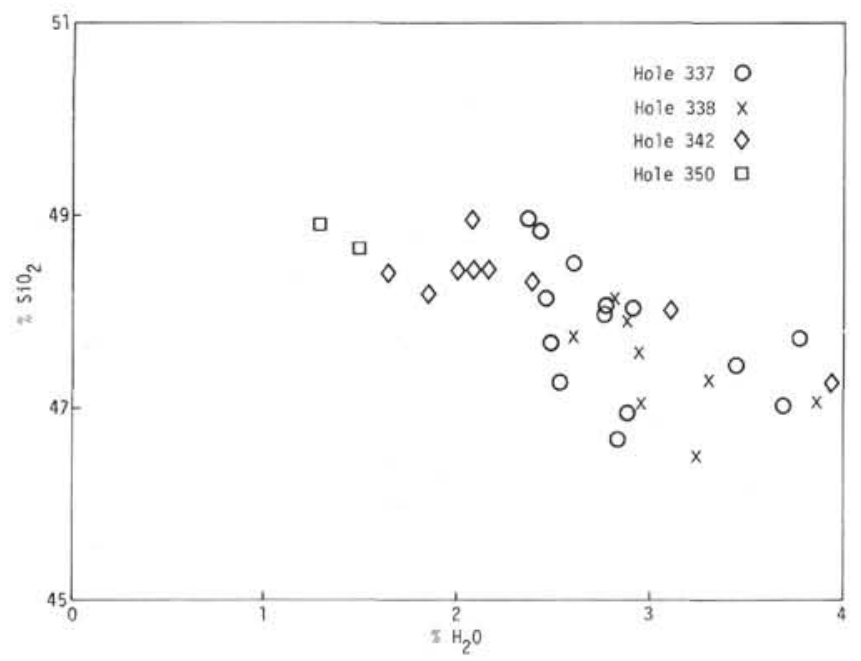

Figure 2. \% $\mathrm{SiO}_{2}$ vs \% $\mathrm{H}_{2} \mathrm{O}$ for basalts from Sites 337, 338,342 , and 350 .

tainty for comparisons of Leg 38 basalts with other basalt provinces.

The main elements, which are normally the basis of volcanic rock classification, must be considered with some restrictions: a decrease of $\mathrm{SiO}_{2}$ and increase of alkalies result in a more alkaline-normative composition of the basalts. On the other hand, an increasing degree of iron oxidation results in a more tholeiitic normative character. To avoid difficulties in our calculations, the $\mathrm{FeO} / \mathrm{Fe}_{2} \mathrm{O}_{3}$ ratio is fixed on an ar- 


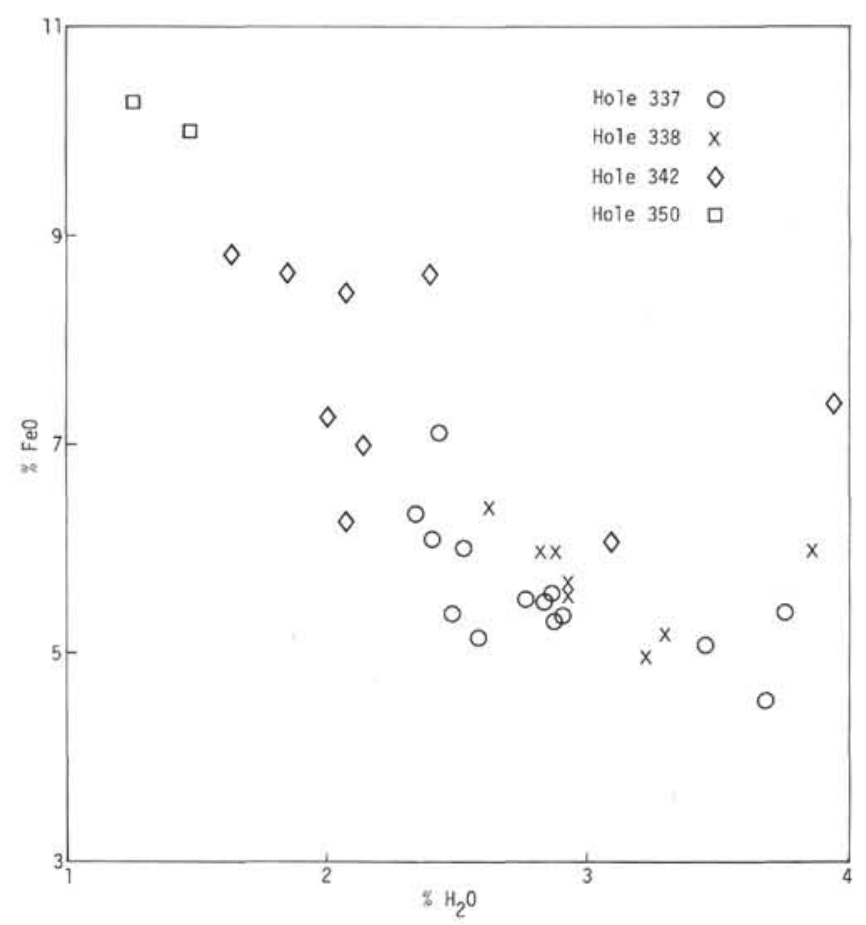

Figure 3. \% $\mathrm{FeO}$ vs \% $\mathrm{H}_{2} \mathrm{O}$ for basalts from Sites 337, 338,342 , and 350 .

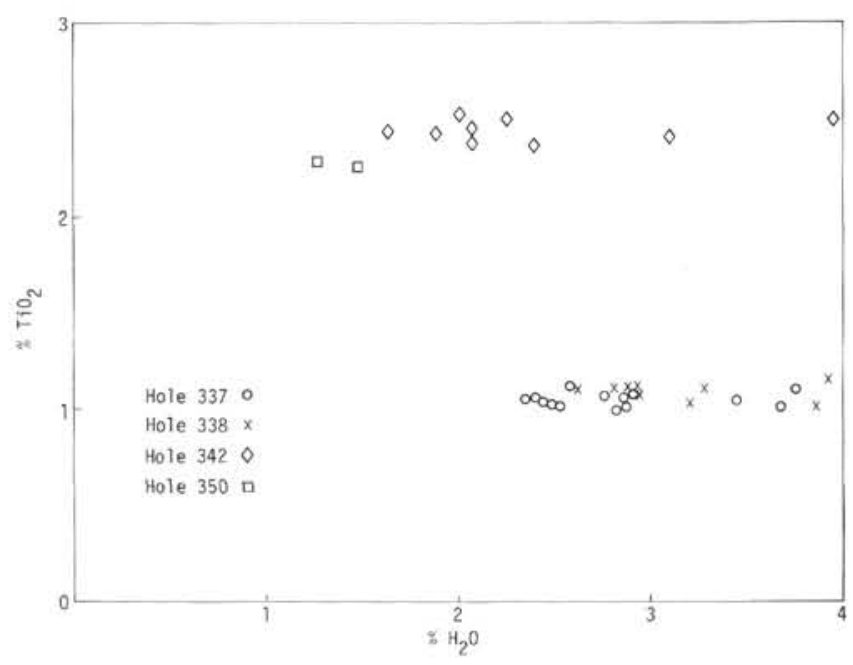

Figure 4. \% $\mathrm{TiO}_{2}$ vs \% $\mathrm{H}_{2} \mathrm{O}$ for basalts from Sites 337, 338,342 , and 350 .

tificial value. However, the gain or loss of other elements cannot be corrected mathematically, so that the normative composition in altered samples is of higher alkalinity than the original melt.

\section{DISCUSSION OF RESULTS}

The model of Schilling and Noe-Nygaard (1974), is derived from the Iceland-Faeroe region and segments of the northern Mid-Atlantic Ridge.

The 3000-meter-thick Faeroe Plateau basalt of 50-60 m.y. age shows a geochemical discontinuity between the middle and upper part of the basalt pile. In the younger series, light RE are depleted together with a depletion of $\mathrm{TiO}_{2}\left(\mathrm{TiO}_{2}<1.5 \%\right)$, and a decrease of the $\mathrm{TiO}_{2} / \mathrm{FeO}$ ratio (below 0.12 ). These observations are explained by a change of volcanic regime derived from the older plume, to one more akin to oceanic type. It should be noted that the Faeroe and Rockall plateaus are separated from the European continent by the Rockall Trough and the Faeroe-Shetland Trough, whose possible formation by spreading lies in an early stage of the separation of North America and Europe (Bott, 1973).

According to Sigvaldason (1974) the previously assumed difference between ocean ridge basalts and Icelandic basalts, expressed mainly in the high iron and low magnesium content of the latter, does not exist. However, a relative enrichment of high iron and low magnesium basalts in Iceland is indicated.

Brooks et al. (1974) have outlined an increase of scattering of incompatible constituents like $\mathrm{K}_{2} \mathrm{O}, \mathrm{TiO}_{2}$, $\mathrm{Rb}, \mathrm{Zr}$, with approach to the Icelandic hot mantle plume from the southwest along the Reykjanes Ridge, with a distinct geochemical high over Iceland. The crystallization index (total $\mathrm{Fe}$ as $\mathrm{FeO} / \mathrm{MgO}$ ) is distinctly different for ridge segments near the Icelandic plume $(\mathrm{FeO} / \mathrm{MgO}=1.86)$, and the Mid-Atlantic Ridge far south of Iceland $(\mathrm{FeO} / \mathrm{MgO}=1.08)$.

Another approach to characterizing basic volcanic rocks from different volcanic settings was done by Pearce and Cann (1973), who constructed discrimination diagrams for dividing basalts with the less mobile elements $\mathrm{Ti}, \mathrm{Zr}, \mathrm{Y}$, and $\mathrm{Nb}$, and for fresh samples with Sr. Basalts erupted within plates (ocean island and continental basalt) can be identified using the Ti-Zr-Y diagram, ocean-floor basalts, and low-potassium tholeiites can be identified using a $\mathrm{Ti}-\mathrm{Zr}$ diagram (Figures 9, 10, 11, and 12). Similar correlation plots were proposed by Ridley et al. (1974) who used the alteration-resistant element pairs $\mathrm{P}_{2} \mathrm{O}_{5}-\mathrm{TiO}_{2}$ (Figure 14) and $\mathrm{Zr}$-Sr (Figure 13) to outline fields for ocean ridge basalts, ocean islands tholeiites, and alkali basalts.

In general, the basalts of Sites 336, 337, 338, 342, 344, 348 , and 350 have a tholeiitic character; in the OL-DIHY-Q-diagram (Figure 5), all samples cluster in the field of either quartz tholeiite or olivine tholeiite. If we abandon the mode of calculation of ferric iron $\left(\mathrm{Fe}_{2} \mathrm{O}_{3}\right.$ $\left.=\mathrm{TiO}_{2}+1.5\right)$ and calculate the norm with lower contents of $\mathrm{Fe}_{2} \mathrm{O}_{3}$, no decisive changes of the normative character towards higher alkalinity are obtained (Figure 6).

We learn, however, from the AFM-diagram (Figure 7: $\mathrm{A}=\mathrm{Na}_{2} \mathrm{O}+\mathrm{K}_{2} \mathrm{O} ; \mathrm{F}=$ total $\mathrm{Fe}$ as $\mathrm{FeO} ; \mathrm{M}=\mathrm{MgO}$ ), that there are different degrees of iron enrichment. The basalts from Site 342 , on the outer V $\phi$ ring Plateau, are highly enriched in iron, as well as in alkalies. Similar, but with lower alkali enrichment, are the basalts from the southern extension of the Jan-Mayen Ridge (Site 350 ), and from the Icelandic Plateau (Site 348). On the other hand, there is a tendency towards a high $\mathrm{Mg}$ content in basalts from Site 336 on the Iceland-Faeroe Ridge, the extinct axis of the Norway Basin (Site 337), and parts of the V $\phi$ ring Plateau (Site 338). Only the intrusive gabbros and diabase of Site 334 (Knipovich Ridge) have a primary high content of alkalies, and are 


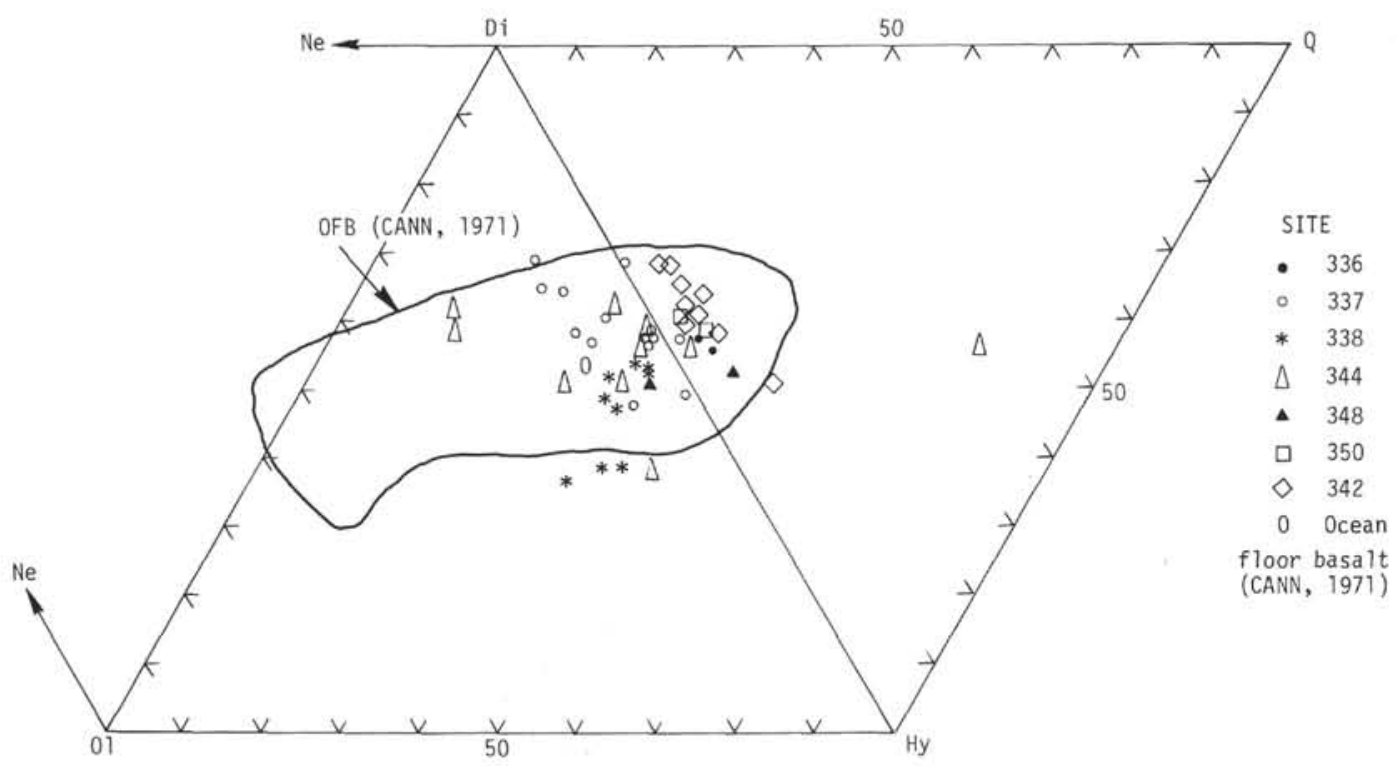

Figure 5. Normative Ne-Ol-Di-Hy-Q diagram of basalts from Sites 336, 337, 338, 344, 348, 342, and 350. Ferric iron calculated as $\mathrm{TiO}_{2}+1.5$.

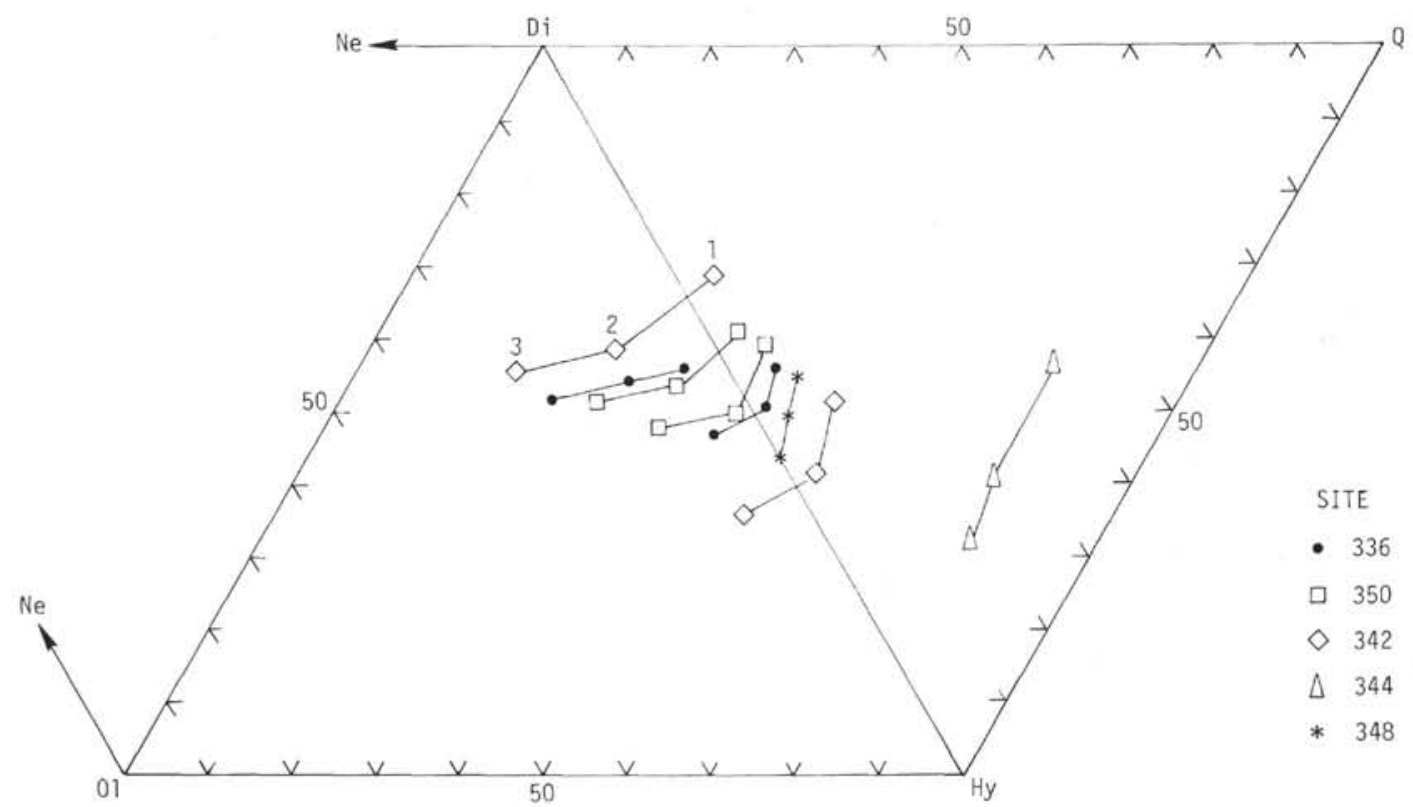

Figure 6. Normative Ne-Ol-Di-Hy-Q diagram of selected samples from Sites 336, 342, 344, 348, and 350. Diagram shows the shifting of analyses depending on the ferric iron calculation: (1) $\mathrm{Fe}_{2} \mathrm{O}_{3}=\mathrm{TiO}_{2}+1.5,(2) \mathrm{Fe}_{2} \mathrm{O}_{3}=1.5$, and $(3) \mathrm{Fe}_{2} \mathrm{O}_{3}=0$.

plotted in the area of calcalkaline basalts. The differentiation trend within this inhomogeneous sill is obvious.

It is of interest, that some of the $\mathrm{FeO} / \mathrm{MgO}$-ratios (total $\mathrm{Fe}$ as $\mathrm{FeO}$ ) are similar to those of Iceland or Reykjanes Ridge near Iceland, whereas the others resemble those of normal ocean floor type of the northern Atlantic ocean (see below):

$$
\text { Site 350: } \mathrm{FeO} / \mathrm{MgO}=2.21
$$$$
\text { Site 342: }=2.18
$$

Reykjanes Ridge (Brooks et al., 1974): $=1.86$

Site 348: $=1.84$

Site 336: $=1.65$

Site 337: $=1.39$

Site 338: $=1.15$

\section{Mid-Atlantic Ridge far south of Iceland}

(Brooks et al., 1974): = 1.08

Sigvaldason (1974) divided the basalts of the eastern volcanic zone in Iceland on the basis of a $\mathrm{Na}_{2} \mathrm{O} / \mathrm{K}_{2} \mathrm{O}$ $\mathrm{K}_{2} \mathrm{O}$ plot (Figure 8) into three groups, which coincide with zones of different pressure and depth during the process of partial melting. These zones are defined by the elements $\mathrm{Ti}$ and $\mathrm{Zr}$, whose concentrations are assumed to be governed by the degree of partial melting. Within the eastern volcanic zone of Iceland, the basalt group with high potassium content is predominant over the group with potassium- and irondepletion and $\mathrm{Mg}$-enrichment, thus indicating different degrees of partial melting at different depths at the 


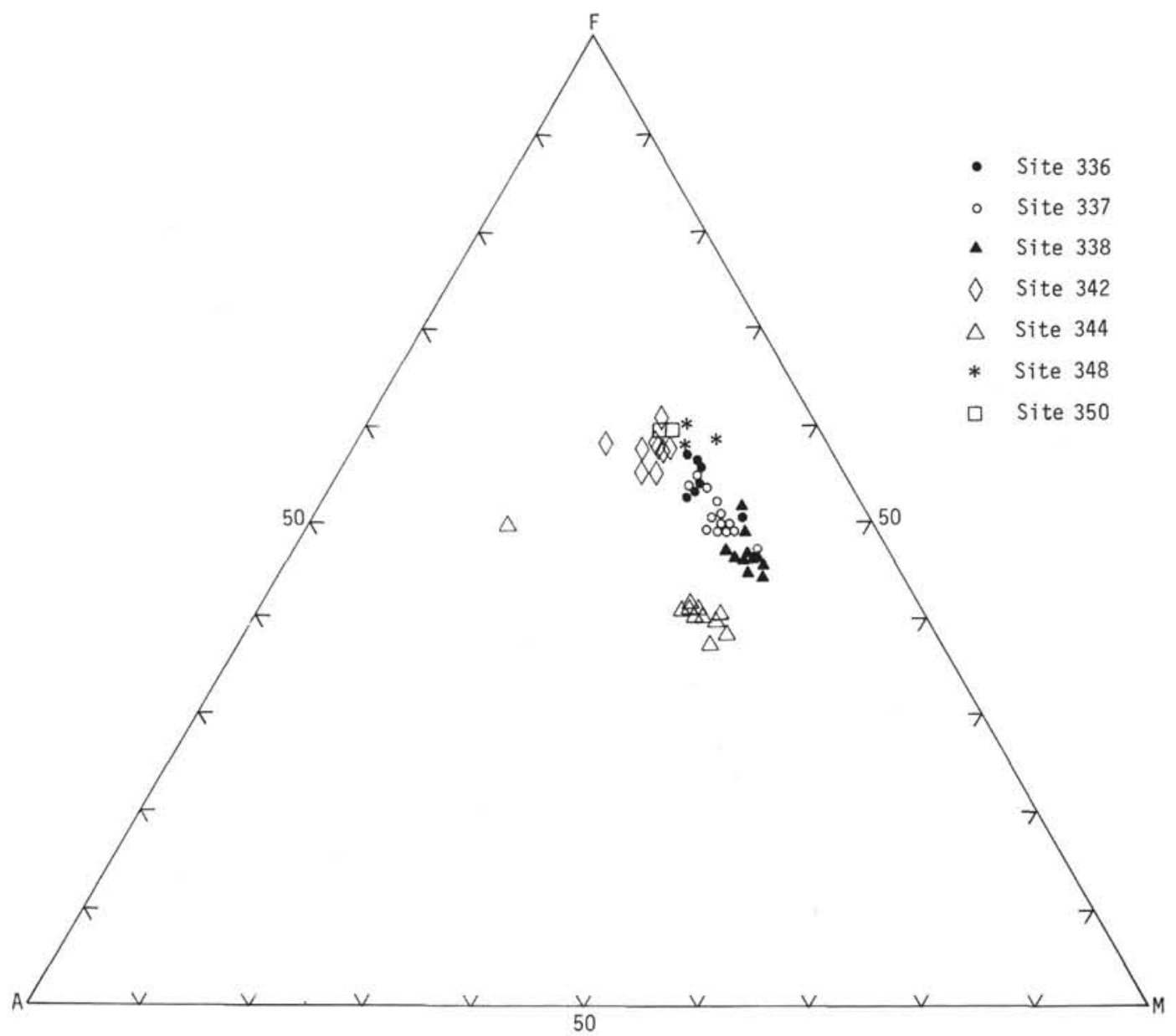

Figure 7. AFM diagram for basalts from Sites 336, 337, 338, 342, 344, 348, and 350. $\mathrm{A}=\mathrm{Na}_{2} \mathrm{O}+$ $\mathrm{K}_{2} \mathrm{O}, \mathrm{F}=$ total $\mathrm{Fe}$ as $\mathrm{FeO}, \mathrm{M}=\mathrm{MgO}$.

same time, and a predominance of low degree partial melting (iron-enriched basalts) in extensive mantle volumes.

In the Leg 38 basalts, there is a depletion of potassium relative to sodium in basalts from Sites 348 , 338 , and 336 relative to the medium value for Ocean Floor Basalts (OFB-Cann, 1971). Site 337 basalts fit well in the range of OFB, whereas Site 342 and 344 basalts are enriched in potassium. According to the different diagrams of the less mobile elements $\mathrm{Ti}, \mathrm{Y}, \mathrm{Zr}$ (Cann, 1971), there are again two groups of sites with a different character of the basalts; whereas at Sites 336, 337,338 , and 348 nearly all samples belong to the Ocean Floor Basalt group (Figures 9, 11) even with a tendency to "Low Potassium Tholeiites" (Sites 337, 348 ), the basalts of Sites 342, 343, 345, and 350 show a strong affinity to "Within Plate Basalts" (Figures 10, 11). An exception are the samples of Site 344, which show an "Ocean Floor Basalt" character, but with a tendency towards more "Calcalkaline Basalts."

These characteristics are affirmed by the $\mathrm{Ti} / \mathrm{Zr}$ correlation plot (Figure 12), where we find again the calcalkaline tendency of Site 344 basalts. The basalts of Sites $342,343,345,350$ with a "Within Plate" tendency, are strongly enriched in $\mathrm{Ti}$ and $\mathrm{Zr}$, and therefore plot-

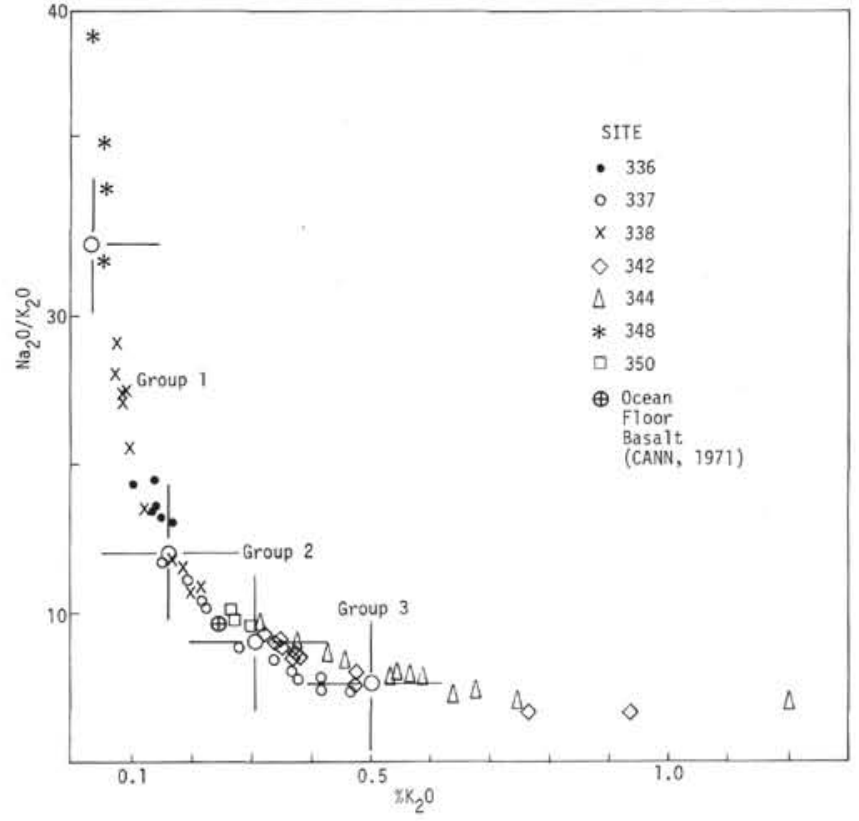

Figure 8. $\mathrm{Na}_{2} \mathrm{O} / \mathrm{K}_{2} \mathrm{O}$ vs $\mathrm{K}_{2} \mathrm{O}$ for basalts from Sites 336, $337,338,342,344,348$, and 350 . 


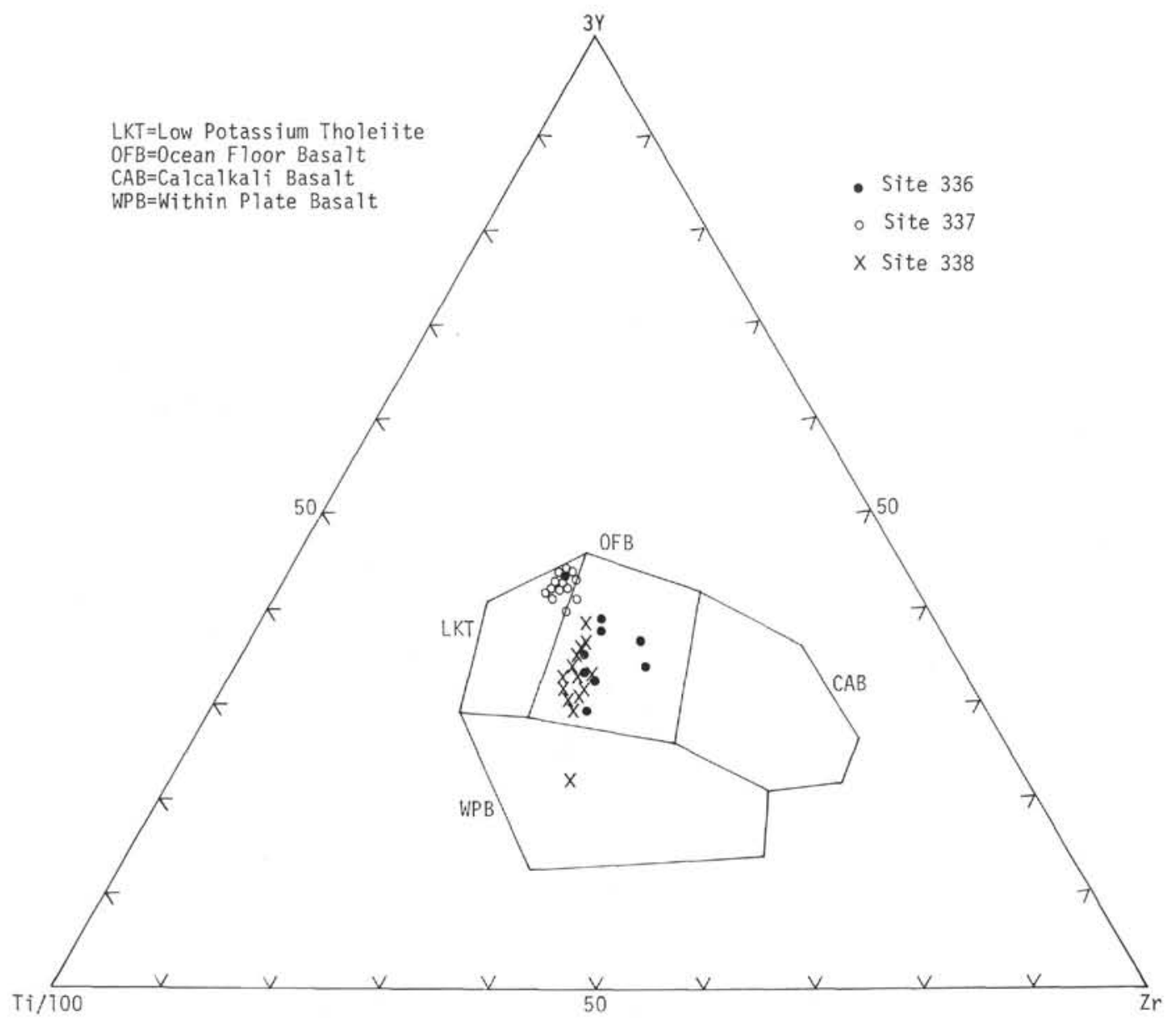

Figure 9. Ti-Zr-Y diagram for basalts from Sites 336, 337, and 338. 


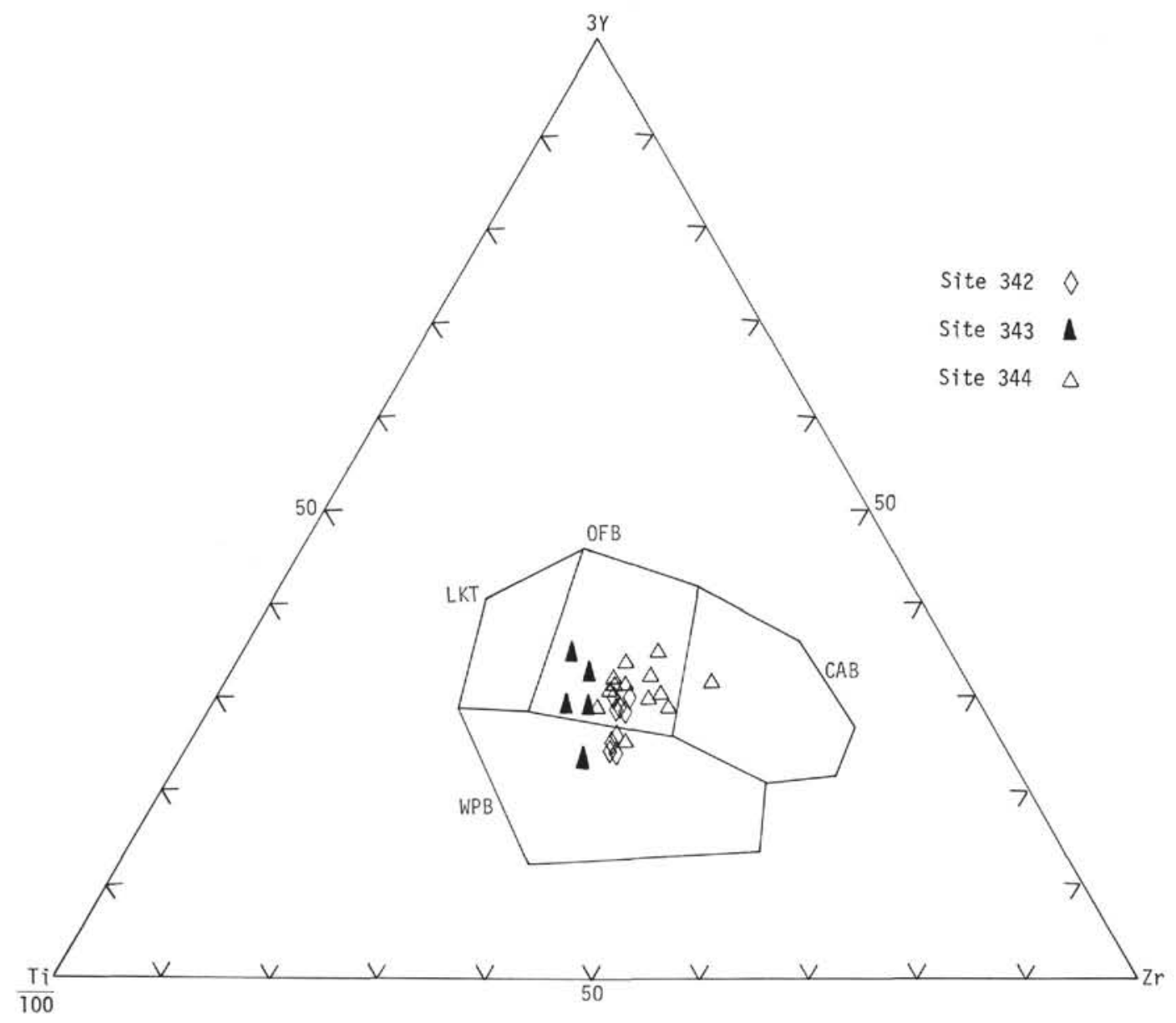

Figure 10. Ti-Zr-Y diagram for basalts from Sites 342, 343, and 344. 


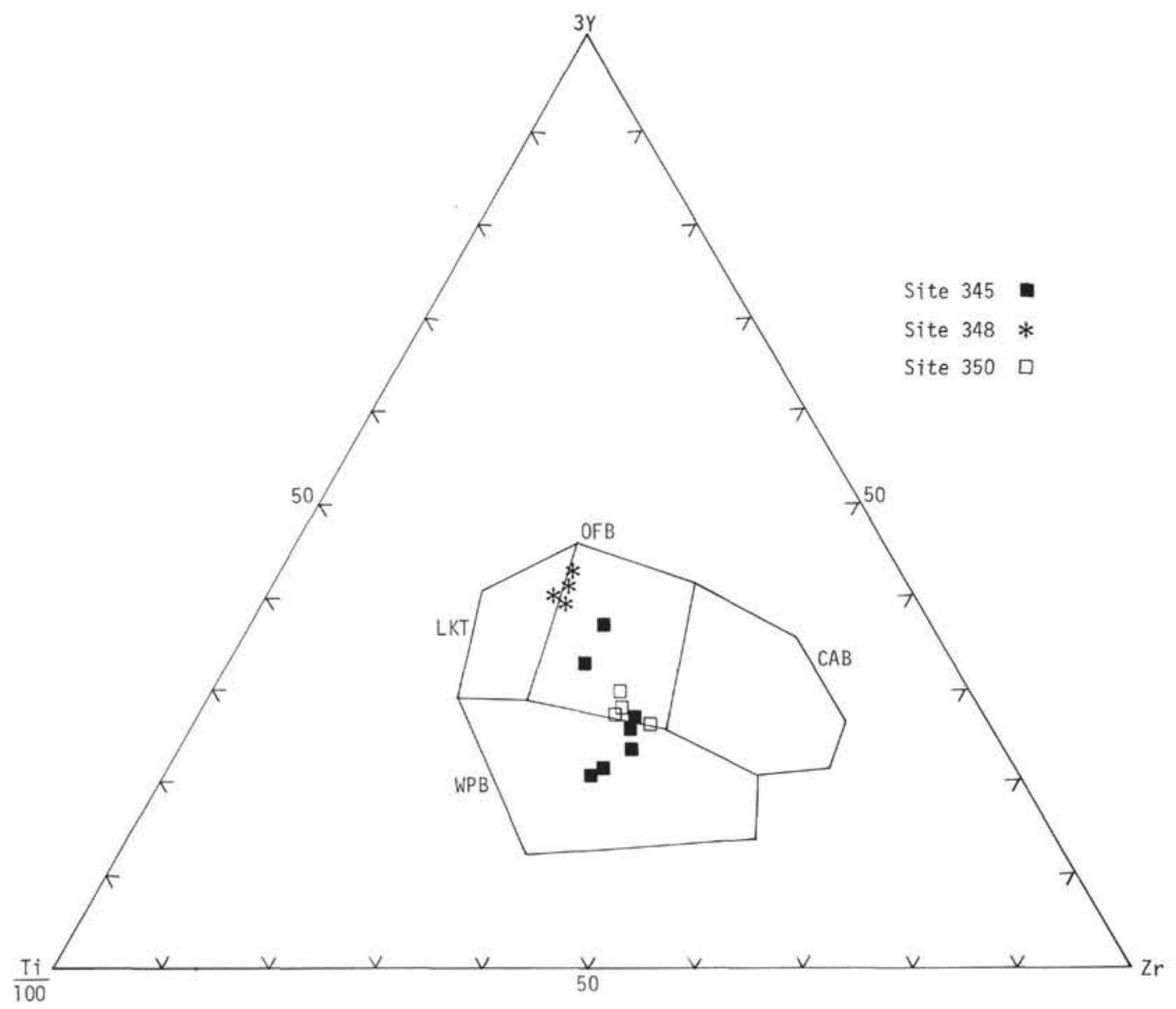

Figure 11. Ti-Zr-Y diagram for basalts from Sites 345, 348, and 350 . 


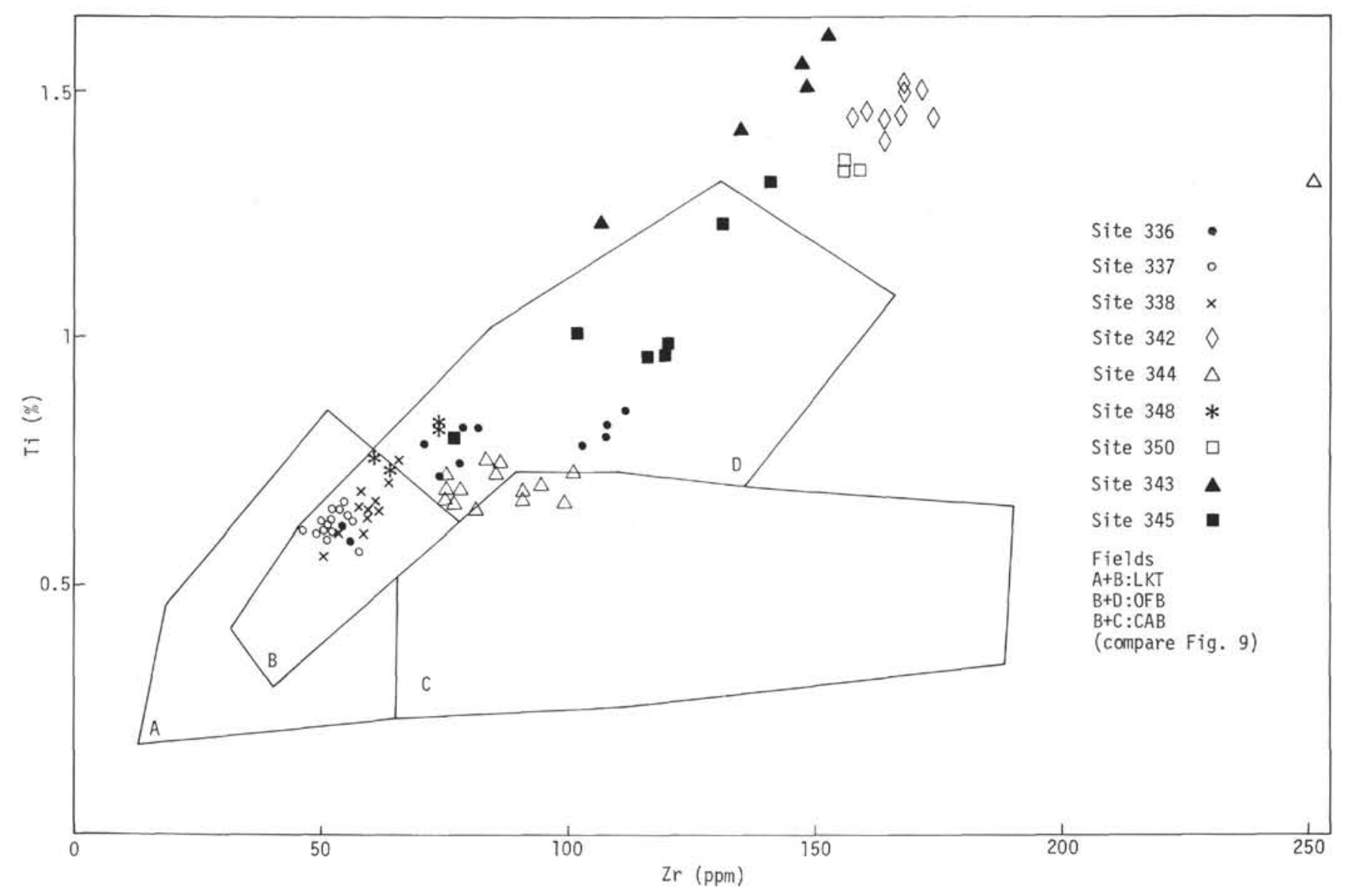

Figure 12. Ti(\%) vs Zr(ppm) for basalts from Sites 336, 337, 338, 342, 343, 344, 345. 
ting outside the fields of "Ocean Floor Basalts," as proposed by Cann (1971).

The division of the two groups is also found, if we use less resistant elements like phosphorus and strontium (Figures 13,14). According to the proposal of Ridley et al., (1974), "Ocean Ridge Basalts" can be divided from "Ocean Island Tholeiite," which correspond to the "Within Plate Basalt" of Cann (1971). In these correlation plots, again, only the rocks of Sites 342,345 , and 350 show an "Ocean Island Tholeiite" trend. An exception are the samples at Site 343, which fall in the field of "Ocean Island Tholeiites" in the $\mathrm{P}_{2} \mathrm{O}_{5}-\mathrm{TiO}_{2}$ correlation plot, but which do not reach the high $\mathrm{Sr}$ values of "Ocean Island Tholeiites." We draw attention to the high degree of alteration of Site 343 basalts. In general, these two plots show a greater scatter of element concentrations between samples of the same site.

If we compare Leg 38 basalts with basalts from Iceland (Sigvaldason, 1974) in Figures 13 and 14, the Icelandic rocks show predominantly "Ocean Ridge" character, but with a strong tendency to "Ocean Island Tholeiite." If we adopt the model of Schilling and NoeNygaard (1974) for the Faeroe-Iceland region, the groups of basalts, defined above by different methods, belong either to plume-derived or ocean ridge magma types (see below):

Hot Mantle Plume type:

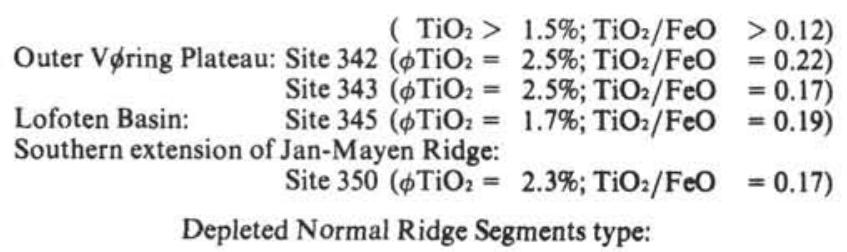

$\left(\mathrm{TiO}_{2}<1.5 \% ; \mathrm{TiO}_{2} / \mathrm{FeO}<0.12\right)$

Iceland Faeroe Ridge: Site $336\left(\phi \mathrm{TiO}_{2}=1.3 \% ; \mathrm{TiO}_{2} / \mathrm{FeO}=0.11\right)$ Extinct axis in the Norway Basin:

Site $337\left(\phi \mathrm{TiO}_{2}=1.1 \% ; \mathrm{TiO}_{2} / \mathrm{FeO}=0.10\right)$

Outer V $\phi$ ring Plateau: Site $338\left(\phi \mathrm{TiO}_{2}=1.1 \% ; \mathrm{TiO}_{2} / \mathrm{FeO}=0.11\right)$

Knipovich Ridge: $\quad$ Site $344\left(\phi \mathrm{TiO}_{2}=1.2 \% ; \mathrm{TiO}_{2} / \mathrm{FeO}=0.15\right)$

Icelandic Plateau: $\quad$ Site $348\left(\phi \mathrm{TiO}_{2}=1.3 \% ; \mathrm{TiO}_{2} / \mathrm{FeO}=0.10\right)$

The $\mathrm{TiO}_{2}$-content and the $\mathrm{TiO}_{2} / \mathrm{FeO}$ ratio (total $\mathrm{Fe}$ as $\mathrm{FeO}$ ) are in good agreement with the limits defined by Schilling and Noe-Nygaard (1974) for both volcanic regimes.

\section{CONCLUSIONS}

Pursuing the magmatic events during the opening of the Norwegian-Greenland Sea, as far as they are recorded in the few sites of Leg 38, it is concluded that after the initial rifting there were produced both magma types in the Eocene (Sites 337, 338, 342, 343, and 350) and in the Eocene-Oligocene time (Sites 336, 337, 350, 345). The Miocene basalts of Site 348 and the Pliocene intrusives of the Knipovich Ridge at Site 344 are of "Ocean Floor" character. We must assume that in Eocene and early Oligocene times, in parts of the Outer
V $\phi$ ring Plateau, there was an influence of the hot mantle plume activity, along with a normal sea-floorspreading magma generation.

If the Jan-Mayen Ridge is really a sliver of the Greenland shelf, split off during the westward migration of the active spreading center before $42 \mathrm{~m} . \mathrm{y}$., then the basalts of Site 350 could be produced by a primary hot mantle plume activity during the early history of separation of Greenland and Jan-Mayen Ridge in late Eocene times.

The late Eocene basalts of "Ocean Floor" character of the Iceland-Faeroe Ridge (Site 336) are similar to the upper basalt series of the Faeroe Islands after decline of mantle plume activity in this region (Schilling and NoeNygaard, 1974). Possibly there exists below the Site 336 basalt layer, a thick sequence of mantle plume-derived basalts, as was observed in the Faeroe basalt pile.

The basalt chemistry of Sites 337 and 348 is in agreement with the tectonic settings in the "extinct" rift axis in the Norway Basin and in the rift-generated Icelandic Plateau, respectively. The strong iron enrichment at Site 348 , in comparison to basalts of the Mid-Atlantic Ridge south of Iceland, is, however, puzzling, because these "Fe" basalts are more typical for the mantle plume-derived basalts, for example, of Iceland.

The transitional character of the early middle Oligocene basalts at Site 345 , in the southern Lofoten Basin, is possibly connected with the nearby JanMayen Fracture Zone, because only from fracture zones, are transitional basalts known within areas of normal ocean floor basalt character.

Until now, a genetic classification of the intrusive basalts of calcalkaline tendency to a specific tectonic setting at Site 344 is not possible.

\section{REFERENCES}

Bott, M.H.P., 1973. The evolution of the Atlantic north of the Faeroe Islands: Implications of continental drift to the Earth Sciences, v. 1.

Brooks, K.C., Jakobsson, S.P., and Campsie, J., 1974. Dredged basaltic rocks from the seaward extensions of the Reykjanes and Snaefellsnes volcanic zones, Iceland: Earth Planet. Sci. Lett., v. 22, p. 320-327.

Cann, J.R., 1971. Major element variations in ocean floor basalts: Phil. Trans. Roy. Soc. London, Ser. A, v. 268, p. 495-506.

Irvine, T.N. and Baragar, W.R.A., 1971. A guide to the chemical classification of the common volcanic rocks: Canadian J. Earth Sci., v. 8, p. 523-548.

Pearce, J.A. and Cann, J.R., 1973. Tectonic setting of basic volcanic rocks determined using trace element analyses: Earth Planet. Sci. Lett., v. 19, p. 290-300.

Ridley, W.I., Rhodes, J.M., Reid, A.M., Jakes, P., Shih, C., and Bass, M.N., 1974. Basalts from Leg 6 of the Deep Sea Drilling Project: J. Petrol., v. 15, p. 140-159.

Schilling, J.G. and Noe-Nygaard, A., 1974. Faeroe-Iceland Plume: Rare-earth evidence: Earth Planet. Sci. Lett., v. 24, p. 1-14.

Sigvaldason, G.E., 1974. Basalts from the center of the assumed Icelandic mantle plume: J. Petrol., v. 15, p. $497-$ 524. 


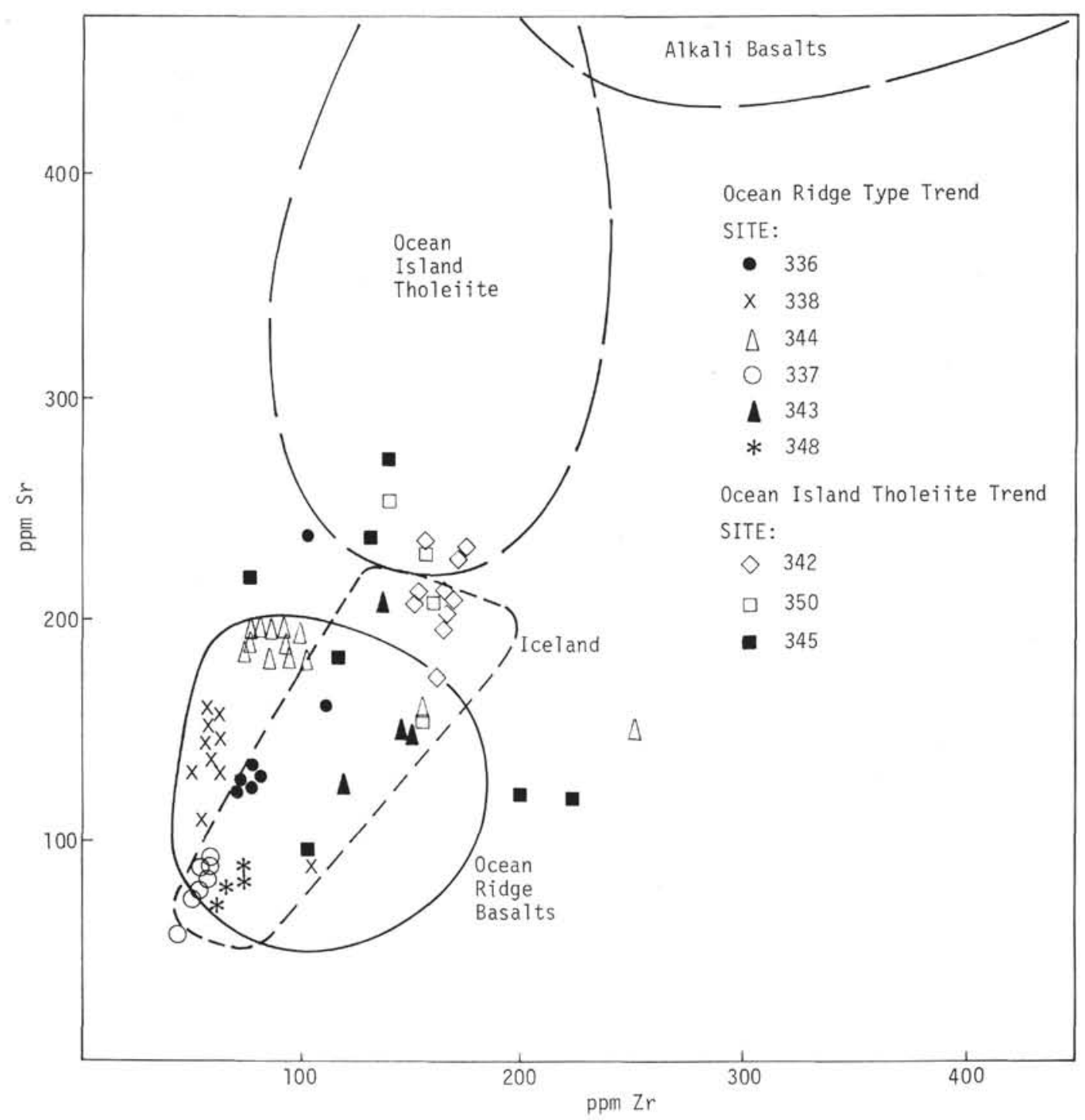

Figure 13. Sr (ppm) vs $\mathrm{Zr}$ (ppm) for basalts from Sites 336, 337, 338, 342, 343, 344, 345, 348, and 350 . 


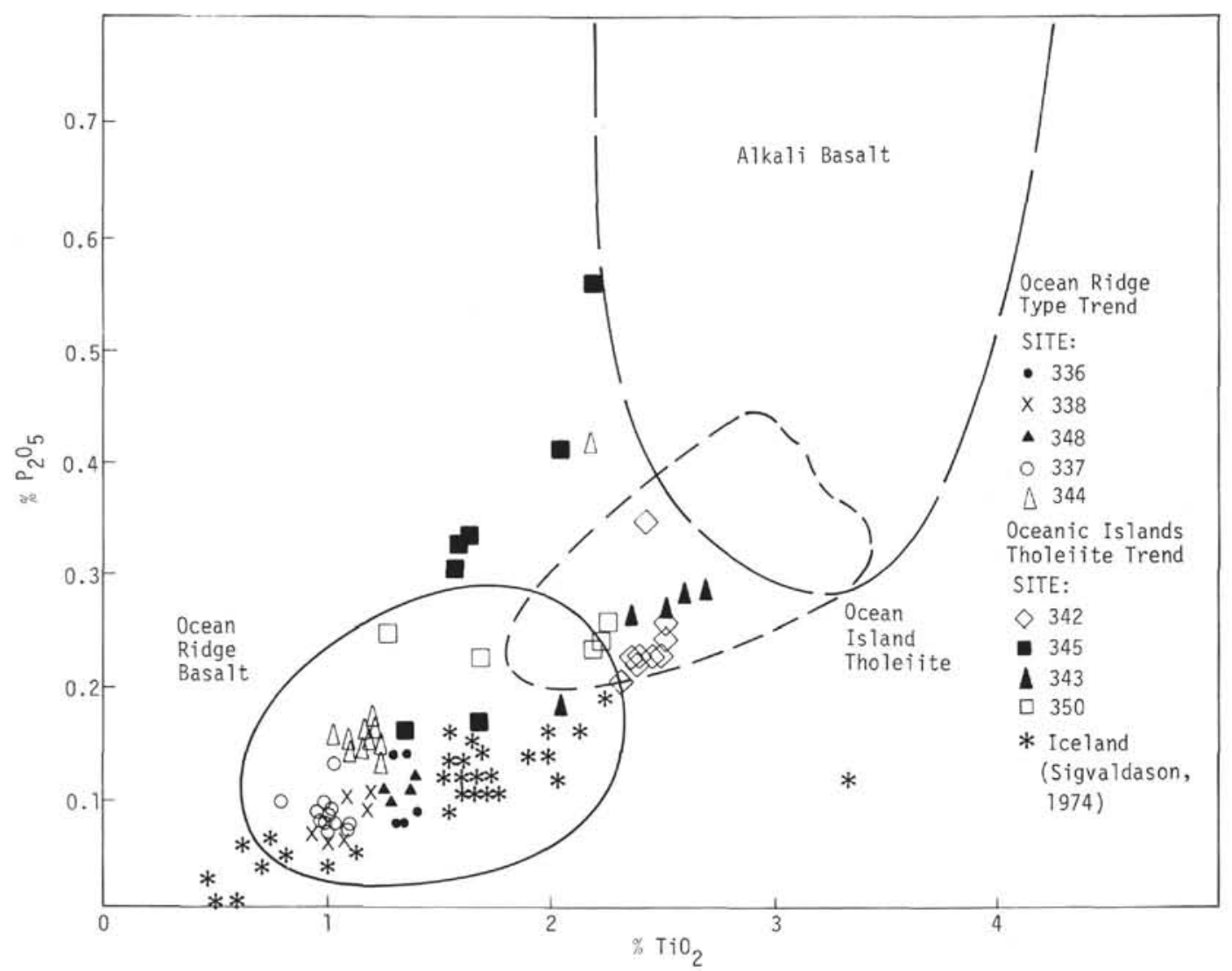

Figure 14. Correlation plots of alteration-resistant element pairs $\left(\mathrm{P}_{2} \mathrm{O}_{5} \%, \mathrm{TiO}_{2} \%\right)$. Fields of various basalt types outlined from Ridley et al., 1974. Basalts from Sites 336, 337, 338, 342, 343, 344, 345,348 , and 350 . 


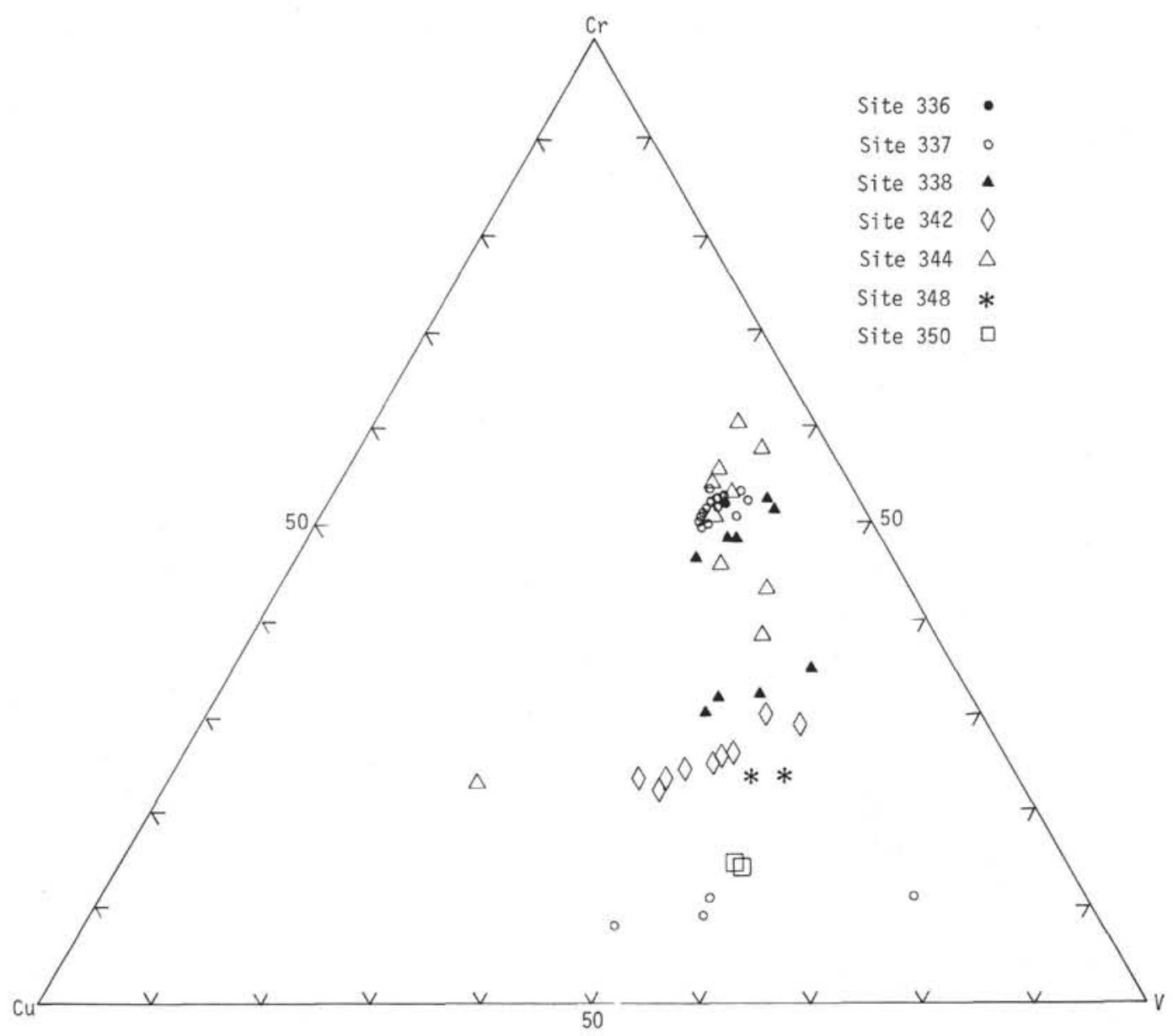

Figure 15. Cr-Cu-V diagram for basalts from Sites 336, 337, 338, 342, 344, 348, and 350. 